\title{
Neurodiagnostic Abnormalities in Patients with
}

\section{Acute Renal Failure}

\author{
EVIDENCE FOR NEUROTOXICITY OF PARATHYROID HORMONE
}

\author{
Jerry D. Cooper, Virginia C. Lazarowitz, and Allen I. Arieff, Kidney Research \\ Laboratories, San Francisco Veterans Administration Hospital and University \\ of California, San Francisco, California 94121
}

\begin{abstract}
A B S T R A C T Neurological abnormalities are a major cause of morbidity in patients with renal failure. The pathophysiology of these neurological changes is unclear, and the effects on them of dialysis and return of renal function have not been well studied. Studies were done in 31 patients who had acute renal failure (ARF), all of whom were either treated with dialysis within 5 days or did not survive. Studies on these patients included the electroencephalogram (EEG), motor nerve conduction velocity, and plasma $\mathrm{Ca}^{++}$ and parathyroid hormone (PTH) levels. Studies were done at the time ARF was diagnosed, after stabilization on dialysis, during the diuretic phase of ARF, and $3 \mathrm{mo}$ after recovery from ARF. In 16 patients with acute or chronic renal failure who did not survive and in nine patients without renal disease who died, measurements were made in brain of content of $\mathrm{Na}^{+}$. $\mathrm{K}^{+}, \mathrm{Cl}^{-}, \mathrm{Ca}^{++}, \mathrm{Mg}^{++}$, and water.
\end{abstract}

In patients with ARF for less than $48 \mathrm{~h}$, despite the fact that there were only modest increases in plasma urea and creatinine, there were striking abnormalities in the EEG. The percent EEG power $<5 \mathrm{~Hz} \pm \mathrm{SE}$ was $41 \pm 8 \% \quad($ normal $=2 \pm 1 \%)$, whereas the percent of frequencies $>9 \mathrm{~Hz}$ was only $22 \pm 6 \%$ (normal $=$ $62 \pm 3 \%$ ). These changes were unaffected by dialysis, but became normal with return of renal function and remained normal at 3 mo follow-up. The motor nerve conduction velocity was unaffected by either ARF or dialysis. In patients with ARF, the brain $\mathrm{Ca}^{++}$ was $46.5 \pm 3.2 \mathrm{meq} / \mathrm{kg}$ dry wt, almost twice the normal value of $26.9 \pm 1.0 \mathrm{meq} / \mathrm{kg}$ dry wt $(P<0.00 \mathrm{l})$. The plasma PTH level was $3.2 \pm 0.6 \mathrm{ng} / \mathrm{ml}$ (normal $<1.5$ $\mathrm{ng} / \mathrm{ml}, P<0.01)$. The increased brain $\mathrm{Ca}^{++}$was not

A preliminary report of this paper was presented at the 8th Annual Meeting of the American Society of Nephrology, Washington, D. C., November 1976. Kidney Int. 10: 556.

Received for publication 22 July 1977 and in revised form 18 January 1978. related to an increased plasma $\left(\mathrm{Ca}^{++}\right)\left(\mathrm{PO}_{4}{ }^{--}\right)$product $\left(r^{2}=0.14, P>0.05\right)$. There was a small but significant decrement in brain $\mathrm{Na}^{+}(P<0.05)$, but brain water, $\mathrm{K}^{+}$, and $\mathrm{Mg}^{++}$were unaffected by ARF.

Thus, in patients with ARF for less than $48 \mathrm{~h}$, the EEG is grossly abnormal and there are elevated levels of PTH in plasma. The PTH appears to have a direct effect on the brain, resulting in an increased brain $\mathrm{Ca}^{++}$content. The EEG abnormalities are unaffected by dialysis, but they become normal with return of renal function and remain normal after $3 \mathrm{mo}$ follow-up. Thus, PTH may be a major uremic toxin, demonstrating evidence for central nervous system toxicity when there are only minimal abnormalities of other biochemical markers of ARF.

\section{INTRODUCTION}

Patients with renal failure may exhibit a number of neurological abnormalities which in recent years have become a major cause of morbidity $(1-3)$. Neurological manifestations are especially marked in patients with acute renal failure, where they are probably best correlated with the rate of development of renal failure rather than any single laboratory value (2).

Assessment of the severity of these neurologic changes in patients with chronic renal failure is often highly subjective. This has led to attempts to quantitate the degree of neurological involvement in chronically uremic patients by using those hospital tests which are commonly available, such as the electroencephalogram (EEG) ${ }^{1}$ and measurement of motor nerve conduction velocity (MNCV). Both peripheral neuropathy and an abnormal EEG are present in a

\footnotetext{
'Abbreviations used in this paper: BUN, blood urea nitrogen; EEG, electroencephalogram; MNCV, motor nerve conduction velocity; PTH, parathyroid hormone.
} 
majority of patients with chronic renal failure (1-7). Both the EEG changes and peripheral neuropathy may return toward normal after partial amelioration of uremia by dialysis $(8,9)$. The causes of these abnormalities are not clear. Many patients with chronic. renal failure have concomitant systemic disease states which can also affect the EEG and MNCV, such as diabetes, hypertension, sepsis, peripheral vascular disease, and hepatic insufficiency. Thus, it may be difficult to separate the effects of renal failure, per se, from those of associated medical conditions (2). Therefore, we elected to study patients with acute, rather than chronic, renal failure. Previous studies from this laboratory have suggested that many of the EEG changes found in dogs with acute renal failure are probably secondary, at least in part, to an increased content of $\mathrm{Ca}^{++}$in brain (10) which appears to be mediated through an effect on brain of increased plasma parathyroid hormone (PTH) levels (11). However, neither the applicability of these studies to man nor their potential for reversibility have been established.

The purpose of the present study was to evaluate the neurological abnormalities which are present in patients with acute renal failure, to determine their pathophysiology, and to study the effects of both dialysis and recovery of renal function on these abnormalities. Investigation of the pathogenesis of these abnormalities included analysis of brain water and electrolyte content in those patients with acute renal failure who did not survive.

\section{METHODS}

Studies were done on a total of 54 patients $^{2}$ who were evaluated at the San Francisco Veterans Administration Hospital over an 18-mo interval. These patients were divided into three groups, as follows: (a) 31 patients had acute renal failure; $(b)$ six patients had chronic renal failure which had been treated with dialysis for at least six months. All of these patients died of causes other than uremia. In the patients with chronic renal failure, measurements were made only of plasma $\mathrm{Ca}^{++}$and phosphate, and of brain content of $\mathrm{Ca}^{++}$and $\mathrm{Mg}^{++}$; (c) 17 patients had no evidence of renal disease, parathyroid disease, or cancer, all of which can affect the EEG. These subjects served as controls. Analysis of brain for content of water and electrolytes was carried out on autopsy specimens from a total of 25 patients, of whom 10 had acute renal failure, six had chronic renal failure, and nine control patients died from miscellaneous causes (bacterial pneumonia, sepsis, pulmonary embolus [3], aspiration pneumonia [2], hemorrhagic pancreatitis, acute myocardial infarction). Among the control patients, three had histories of alcoholic cirrhosis,

\footnotetext{
${ }^{2}$ Raw data on individual patients has been deposited with the National Auxiliary Publications Service (NAPS) as NAPS document No. 03220. This information may be ordered from ASIS/NAPS, Microfiche Publications, P. O. Box 3513, Grand Central Station, New York 10017. Remit in advance $\$ 3.00$ for microfiche copy, or for photocopy, $\$ 5.00$ up to 20 pages plus $25 \notin$ for additional pages. Checks should be made payable to Microfiche Publications.
}

two had severe peripheral vascular disease, one had chronic obstructive pulmonary disease, one had chronic congestive heart failure, and one was admitted with a fracture of the femur.

For the purposes of this study, acute renal failure was defined as a rapid deterioration in renal function as manifested by a mean rise in blood urea nitrogen (BUN) of at least 20 $\mathrm{mg} / \mathrm{dl}$ per day and(or) of serum creatinine of at least $1 \mathrm{mg} / \mathrm{dl}$ per day such that serum creatinine exceeded $4 \mathrm{mg} / \mathrm{dl}$ within 3 days of the initial insult. All but 4 of the 31 patients with acute renal failure were oliguric (urine output $<400$ $\mathrm{ml} /$ day) and the causes were toxic nephropathy (phenacetin [2], meglumine diatrizoate, methicillin, trichloroethylene) in five patients, postoperative (cardiac valve replacement [3], coronary artery bypass graft [3], ruptured abdominal aneurysm [2], perforated peptic ulcer [2], aorta-femoral artery bypass graft [2], nephrectomy [2], large bowel obstruction with perforation [2], leg amputation, craniotomy, and exploratory laparotomy) in 19 patients, and no single obvious etiology in the others. Among the 19 patients with postoperative renal failure, six had shock and five had severe sepsis. All surviving patients were treated with dialysis within 5 days. Patients who had a milder degree of acute renal failure such that dialytic therapy was not required were not included in the study. These patients had a serum creatinine which stabilized at less than $4 \mathrm{mg} / \mathrm{dl}$ within 3 days of the onset of acute renal failure. Likewise, patients with known preexisting renal insufficiency, as evidenced by a BUN exceeding $30 \mathrm{mg} / \mathrm{dl}$ and(or) serum creatinine in excess of $2 \mathrm{mg} / \mathrm{dl}$, were also excluded from the study. In addition, patients whose acute renal failure was due to either parenchymal renal disease, such as rapidly progressive glomerulonephritis, or to systemic disease states, such as lupus erythematosus, malignant hypertension or polyarteritis, were also excluded.

Studies done on patients who satisfied these criteria included the standard EEG, MNCV, and serum PTH, phosphate $\left(\mathrm{PO}_{4}^{---}\right)$, and calcium $\left(\mathrm{Ca}^{++}\right)$levels. In those patients who did not survive, measurements were made in brain of the content of $\mathrm{Ca}^{++}, \mathrm{Mg}^{++}, \mathrm{Na}^{+}, \mathrm{K}^{+}, \mathrm{Cl}^{-}$, and water. In these patients, death was attributed to concomitant diseases rather than renal failure per se.

EEG recordings were done with a Beckman Accutrace 8-channel electroencephalograph (Beckman Instruments, Inc., Fullerton, Calif.) with subdermal needle electrodes with a time constant of $0.16 \mathrm{~s}$ and muscle filter set at $30 \mathrm{~Hz}$. The EEG was analyzed by visual frequency analysis similar to that described by Engel et al. (12) and Laidlaw (13). A 13-s representative segment of the right temporo-occipital lead was selected and measurements of frequency distribution were made (13). All waves in the frequency classes 1-13 $\mathrm{Hz}$ were included in the analysis. The number of waves in each frequency class was counted and the percentage of all waves having the same duration was calculated. The average height of all the waves present in each particular frequency class was then measured in millimeters, and the result was multiplied by the percentage of waves present for that frequency class. The resulting number expressed the area (or power) occupied by each frequency of waves for the EEG segment being analyzed. The total EEG segment area was calculated by adding the areas of all frequency classes present. The percentage of the total EEG area occupied by all waves below $5 \mathrm{~Hz}$ was then calculated. This gave the percent EEG power less than $5 \mathrm{~Hz}$, which has been shown to be a useful measurement for the quantitative of the presence of abnormal slow waves in patients with metabolic brain disease (7-9). These techniques have previously been described from this laboratory (10).

The MNCV was measured in the peroneal nerve with a TECA TE-4 Electromyograph system (TECA Corp., White 
Plains, N. Y.), by methods which have been described (14) For at least 15 min before MNCV measurements were done, the patients were reclining in the study room, which had an ambient temperature of $\sim 22^{\circ} \mathrm{C}$.

EEG and MNCV studies were done at four intervals. (a) As soon as the diagnosis of acute renal failure had been established: this was usually within 48 h of the insult which caused the renal failure (12 of 16 patients), except in four patients with postoperative acute renal failure who were transferred from other hospitals. In these four patients, EEG and MNCV studies were done $4-7$ days after the diagnosis of acute renal failure, and the mean $\pm \mathrm{SE}$ for all 16 patients was $2.8 \pm 0.4$ days: (b) After the patient had been stabilized on dialysis: all patients evaluated at this time had received at least six treatments with dialysis over the 2 -wk interval after the diagnosis of acute renal failure, and the day before their next dialysis all had blood urea nitrogen values below $75 \mathrm{mg} / \mathrm{dl}$ and serum creatinine of less than $7 \mathrm{mg} / \mathrm{dl}$. (c) During the recovery (diuretic) phase of acute renal failure: this was defined as a spontaneous diuresis in excess of $800 \mathrm{ml} /$ day, with a fall in BUN and serum creatinine without dialysis. (d) After recovery from acute renal failure: this was at least $3 \mathrm{mo}$ after discharge from the hospital.

Plasma immunoreactive PTH levels were measured at the time of diagnosis of acute renal failure (1 $1 / 2-3$ days after the inciting event) at the same time the initial EEG was obtained. PTH was determined by radioimmunoassay ${ }^{3}$ utilizing antisera to bovine PTH (15). The upper limit of normal for the assay was $1.5 \mathrm{ng} / \mathrm{ml}$.

In 10 patients who died with acute renal failure, nine patients who died without evidence of renal disease, parathyroid disease, or cancer, and in four patients who died with chronic renal failure, measurements were made of the content of $\mathrm{Ca}^{++}, \mathrm{Mg}^{++}, \mathrm{Na}^{+}, \mathrm{K}^{+}, \mathrm{Cl}^{-}$, and water in brain cortical gray matter and subcortical white matter. The brain tissue for analysis was obtained from the anterior frontal lobe of autopsy specimens, consent having been obtained from the next of kin. The analytic methods have been published previously from this laboratory $(11,16,17)$. Briefly, after removal of the ependyma, cortical gray matter and subcortical white matter were separated by blunt dissection (17). Triplicate samples $(\sim 0.4 \mathrm{~g}$ each $)$ were placed in tared conical flasks and weighed to the nearest $0.1 \mathrm{mg}$. After oven drying $\left(105^{\circ} \mathrm{C}\right.$ for $\left.48 \mathrm{~h}\right)$ to determine water content, the samples were extracted in $0.75 \mathrm{~N}$ nitric acid. Electrolytes were measured in the supernate: $\mathrm{Ca}^{++}$and $\mathrm{Mg}^{++}$by atomic absorption spectrophotometry (16), $\mathrm{Na}^{+}$and $\mathrm{K}^{+}$by flame photometry, and $\mathrm{Cl}^{-1}$ by potentiometric titration (17). In addition, measurements in plasma of $\mathrm{Na}^{+}, \mathrm{K}^{+}, \mathrm{Cl}^{+}$, phosphate, urea nitrogen, creatinine and glucose, and arterial $\mathrm{pH}, \mathrm{PO}_{2}, \mathrm{PCO}_{2}$ and bicarbonate were made at the time acute renal failure was diagnosed and at frequent intervals thereafter.

\section{RESULTS}

EEG recordings were done on 16 patients during the course of acute renal failure and after recovery of renal function. The mean $\pm \mathrm{SE}$ age of these patients was $54 \pm 5$ yr. Because of the substantial mortality, all patients were not studied at each interval. As shown in Fig. 1, the EEGs of all patients were grossly abnormal when the diagnosis of acute renal failure was first established. The percent EEG power $<5 \mathrm{~Hz}$, which

${ }^{3}$ PTH measurements were done by Smith Kline Clinical I aboratory, Inc., Burlingame, Calif.

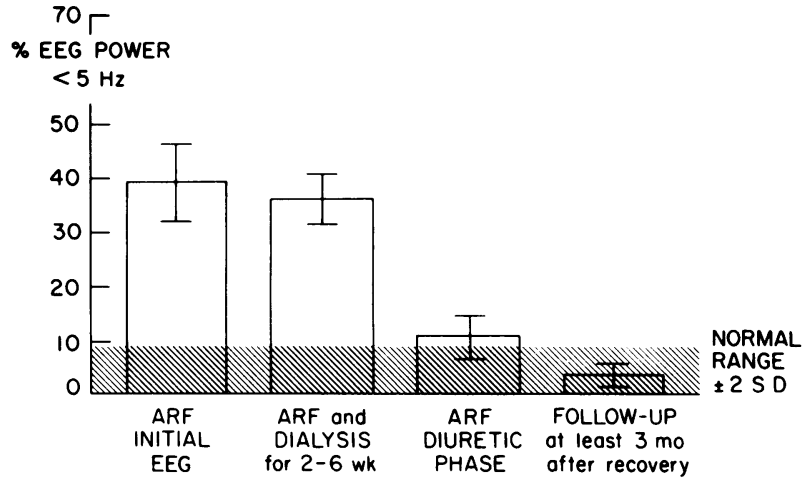

Figure 1 Percent EEG power less than $5 \mathrm{~Hz}$ in 16 patients with acute renal failure (ARF). The normal range is shown in the cross-hatched area. In patients with ARF, there is a highly significant increase in the percent EEG power below $5 \mathrm{~Hz}$, which is an indicator of the presence of abnormal slow waves. This is not affected by dialysis, but becomes normal with return of renal function.

is a standard measurement of the percentage of total EEG power devoted to abnormal slow waves, was $41 \pm 8 \% \pm \mathrm{SE}$. The comparable value in a normal population (10 subjects) with a similar age distribution (50$60 \mathrm{yr})$ was $2 \pm 1 \%(P<0.001)$.

After treatment with dialysis for 2-6 wk, despite the fact that all patients were well dialyzed by conventional criteria, there was essentially no significant improvement in the EEG (percent EEG power $<5 \mathrm{~Hz}$ $=36 \pm 5 \%$ ) (Fig. 1).

Before the last dialysis prior to the diuretic phase of acute renal failure, all patients had BUN less than $70 \mathrm{mg} / \mathrm{dl}$, serum creatinine below $6 \mathrm{mg} / \mathrm{dl}$, and plasma bicarbonate above $18 \mathrm{meq} / \mathrm{liter}$. The serum $\mathrm{Ca}^{++}$and $\mathrm{PO}_{4}^{--}$were $9 \pm 0.3 \mathrm{mg} / \mathrm{dl}$ and $4 \pm 0.8 \mathrm{mg} / \mathrm{dl}$, respectively. However, when the patients entered the diuretic phase of acute renal failure, within $36 \mathrm{~h}$ there was a highly significant $(P<0.01)$ improvement in the EEG (percent power $<5 \mathrm{~Hz}=12 \pm 4 \%$ ), so that both the percent EEG power $<5 \mathrm{~Hz}$, and the percent of frequencies $>9 \mathrm{~Hz}$ were not different $(P>0.1)$ from normal values (Figs. 1 and 2 ).

Studies of MNCV were done on 10 patients with acute renal failure. When compared to the values for age-matched controls, there were no significant changes observed during the course of their acute renal failure. When the diagnosis of acute renal failure was first established ( $2.8 \pm 0.4$ days), the MNCV was $42 \pm 2 \mathrm{~m} / \mathrm{s}$, which was not different from that of normal age-matched controls $(47 \pm 4 \mathrm{~m} / \mathrm{s})$. When these patients had been treated with hemodialysis for at least $2 \mathrm{wk}$, the MNCV was $40 \pm 2 \mathrm{~m} / \mathrm{s}$, again not different from normal. Neither the MNCV studies done during the diuretic phase of acute renal failure $(44 \pm 2 \mathrm{~m} / \mathrm{s})$, nor those done at least $3 \mathrm{mo}$ after recovery from acute renal failure $(40 \pm 2 \mathrm{~m} / \mathrm{s})$ were different from normal values. 


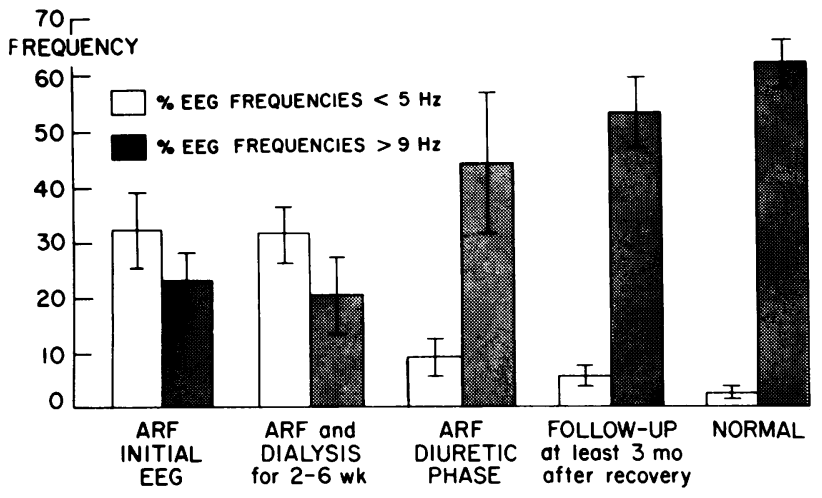

Figure 2 Percent of EEG frequencies below $5 \mathrm{~Hz}$, and above $9 \mathrm{~Hz}$. The normal values are on the right. In patients with acute renal failure (ARF), there are significant changes in both those frequencies above $9 \mathrm{~Hz}$ and those below $5 \mathrm{~Hz}$. These changes are unaffected by dialysis, but become normal with return of renal function.

To determine possible causes of the observed EEG abnormalities, studies of brain $\mathrm{Na}^{+}, \mathrm{K}^{+}, \mathrm{Cl}^{-}, \mathrm{Mg}^{++}$, $\mathrm{Ca}^{++}$, and water content were done in 10 of the patients who died with acute renal failure. In these 10 patients, the time $\pm \mathrm{SE}$ from onset of renal failure to death was $9.4 \pm 3.1$ days. As shown in Table I and Fig. 5, there was a highly significant increase in brain content of calcium $\left(\mathrm{Ca}^{++}\right)$when compared to nine agematched control patients who died without renal failure, parathyroid disease, or cancer. In brain gray matter, $\mathrm{Ca}^{++}$content $\pm \mathrm{SE}$ in patients with acute renal failure was $46.5 \pm 3.2 \mathrm{meq} / \mathrm{kg}$ dry wt (normals $=27.0 \pm 1.0 \mathrm{meq} /$

TABLE I

Effects of Acute Renal Failure (ARF) on Brain Electrolyte Content in Man

\begin{tabular}{llllllll}
\hline & $\mathrm{H}_{2} \mathrm{O}$ & $\mathrm{Na}^{+}$ & $\mathrm{K}^{+}$ & $\mathrm{Cl}^{-}$ & $\mathrm{Ca}^{++}$ & $\mathrm{Mg}^{++}$ \\
\hline glhg wet wt & & meq/kg dry wt
\end{tabular}

Gray

matter

Mean

$\pm \mathrm{SE}$

Normal

(9)

$85.84 \quad 691$

312

Mean ARF

0.57

691

16

598

26.9

62.7

$\pm \mathrm{SE}$

(10)

$85.39 \quad 555^{*} \quad 315$

64
444

1.0

2.2

0.56

38

$6.5 \$ \quad 64.4$

White

matter

Mean

\pm SE

Mean

Normal

(9)

71.34

225

163

$\begin{array}{ll}198 & 10.1\end{array}$

30.3

ARF

(10) 71.04

71.04
0.56

$171^{*}$

161

$18 \quad 1.4$

$133 \S 13.8$

$13 \quad 1.0$

$\pm \mathrm{SE}$

$* P<0.05$ vs. control.

$\ddagger P<0.001$ vs. control.

$\S P<0.01$ vs control.

( ) $=$ No. of patients. kg dry wt, $P<0.001)$. Brain magnesium $\left(\mathrm{Mg}^{++}\right)$content was not different from normal values in either white or gray matter (Fig. 3). As shown in Table I, $\mathrm{Na}^{+}$content of brain gray matter was significantly less in patients with acute renal failure than in the control group $(P<0.05)$. There were also significant decrements in brain white matter content of $\mathrm{Na}^{+}(P<0.05)$ and $\mathrm{Cl}^{-}(P<0.01)$ when compared to normal values (Table I). Neither $\mathrm{K}^{+}$nor water content were different in acute renal failure patients versus age-matched controls (Table I).

Possible reasons for the striking elevations in brain $\mathrm{Ca}^{++}$were then investigated, including measurements of serum PTH activity. 12 patients with acute renal failure had serum PTH determinations done when the diagnosis of acute renal determinations was first established. There was a significant increase in serum PTH in the acute renal failure patients to $3.2 \pm 0.6 \mathrm{ng} / \mathrm{ml}$ (normal $<1.5 \mathrm{ng} / \mathrm{ml}, P<0.01$ ), as shown in Fig. 4. Serum $\mathrm{Ca}^{++}$in these same patients $( \pm \mathrm{SD})$ was $7.6 \pm 1.0$ $\mathrm{mg} / \mathrm{dl}$, which is significantly less than normal $(9.6 \pm 0.6$ $\mathrm{mg} / \mathrm{dl}, P<0.01$ ), and serum $\mathrm{PO}_{4}^{---}$was $5.6 \pm 1.0 \mathrm{mg} / \mathrm{dl}$ (normal $=3.8 \pm 0.4 \mathrm{mg} / \mathrm{dl}, P<0.01$ ).

Because elevations in serum $\left(\mathrm{Ca}^{++}\right)\left(\mathrm{PO}_{4}{ }^{--}\right)$product may produce calcifications in many soft tissues, studies were undertaken to determine any possible relationship of the serum $\left(\mathrm{Ca}^{++}\right)\left(\mathrm{PO}_{4}^{---}\right)$product to brain $\mathrm{Ca}^{++}$content in our patients. Measurements of brain $\mathrm{Ca}^{++}$were compared to plasma $\left(\mathrm{Ca}^{++}\right)\left(\mathrm{PO}_{4}^{---}\right)$product in nine patients who had died of various causes (other than cancer) and who had normal renal and parathyroid function, in six patients with chronic renal failure who had died of various causes, and in nine patients who had died during the course of acute renal

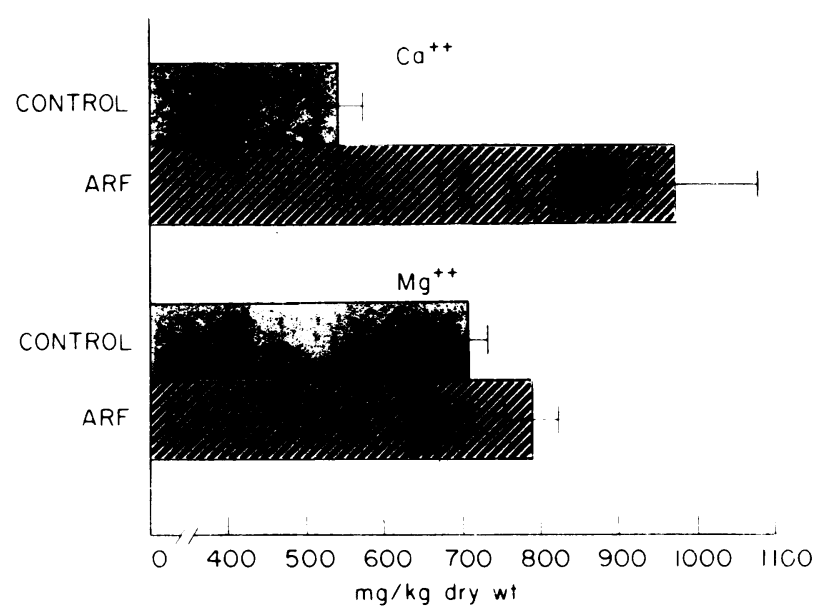

Figure 3 The brain (cortical gray matter) $\mathrm{Ca}^{++}$and $\mathrm{Mg}^{++}$ content in 9 normal subjects and 10 patients with acute renal failure (ARF). There is a highly significant increase of brain $\mathrm{Ca}^{++}$in patients with ARF $(P<0.001)$, but brain $\mathrm{Mg}^{++}$is unaffected. $\left(\mathrm{Ca}^{++}=20.04 \mathrm{mg} / \mathrm{meq}\right.$ and $\mathrm{Mg}^{++}=12.16 \mathrm{mg} / \mathrm{meq}$.) 


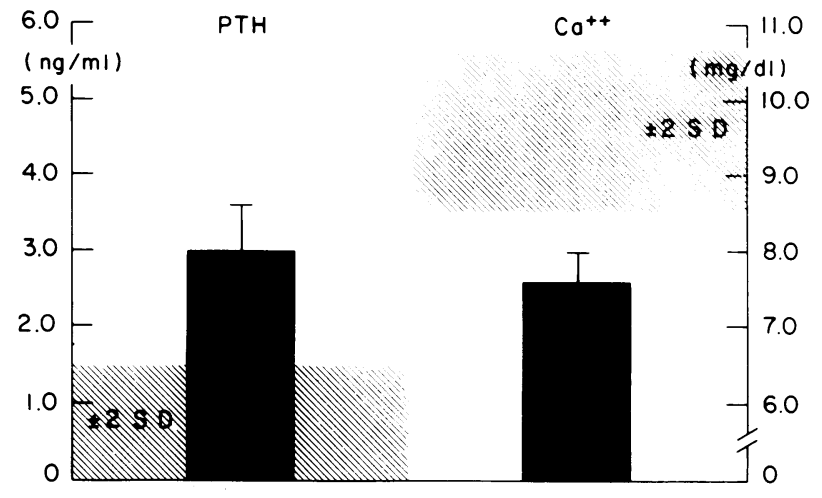

FIGURE 4 Plasma levels of parathyroid hormone (PTH) and $\mathrm{Ca}^{++}$in patients with acute renal failure (ARF). PTH levels are more than twice the upper limit of normal $(P<0.01)$ and plasma $\mathrm{Ca}^{++}$is significantly less than normal $(P<0.01)$. The shaded areas show normal ranges for $\mathrm{Ca}^{++}$and PTH.

failure. In each case, the highest serum $\left(\mathrm{Ca}^{++}\right)\left(\mathrm{PO}_{4}^{---}\right)$ product during the hospitalization before death was noted and the results are shown in Fig. 5. There was no significant correlation between brain $\mathrm{Ca}^{++}$content and plasma $\left(\mathrm{Ca}^{++}\right)\left(\mathrm{PO}_{4}^{---}\right)$product in these 24 patients $\left(r^{2}=0.14, P>0.05\right)$.

\section{DISCUSSION}

These studies show that in patients with acute renal failure, there are marked abnormalities in the EEG at a time when there are only minimal changes in those blood chemistries which are commonly used as clinical markers of renal function (serum urea and creatinine). Associated with the EEG abnormalities are substantial elevations in plasma PTH levels accompanied by significant increases in brain content of $\mathrm{Ca}^{++}$. The initially abnormal EEG findings are not altered by hemo-

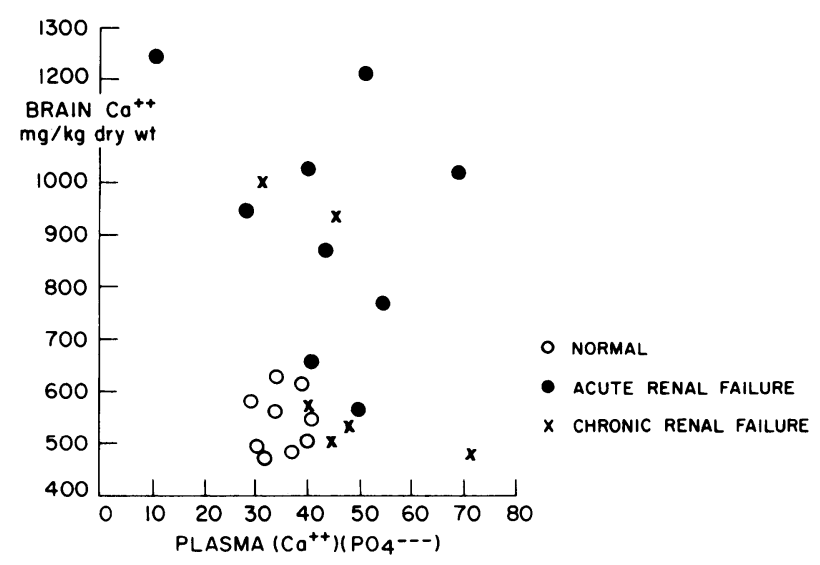

FIgURE 5 The relationship between brain $\mathrm{Ca}^{++}$content and plasma $\left(\mathrm{Ca}^{++}\right)\left(\mathrm{PO}_{4}{ }^{--}\right)$product in 24 patients. There is no significant correlation $(r=0.37 ; P=N S)$. dialysis, but approach normal values during the diuretic phase of acute renal failure, and are completely normal 3 mo after return of renal function. Acute renal failure, in contrast, did not have a significant effect on MNCV.

The exact causes of the EEG changes in these patients with acute renal failure are not clear. Previous studies have shown that in patients with either acute or chronic renal failure, similar EEG changes can not be related to any number of abnormalities in commonly measured blood chemistries $(2,8)$. The EEG abnormalities may in some manner be related either to the acute elevation of plasma PTH (Fig. 4) or to concomitant increases in brain $\mathrm{Ca}^{++}$content (Fig. 3). Previous studies in both patients $(18,19)$ and laboratory animals (20) with acute renal failure have revealed elevated levels of PTH, but not this soon after the diagnosis. Data from the present study show evidence of elevated PTH levels in patients less than $48 \mathrm{~h}$ after the onset of acute renal failure (Fig. 4).

In experimental animals, the EEG abnormalities induced by injections of parathyroid extract are similar to those associated with acute renal failure $(10,21)$. In previously parathyroidectomized dogs with acute renal failure, the EEG is essentially normal (10). There are several recent studies which relate brain $\mathrm{Ca}^{++}$content to PTH and EEG changes. After 3 days of either acute renal failure or PTH injection in dogs, brain $\mathrm{Ca}^{++}$is elevated and the EEG is abnormal $(10,21)$. After cessation of the PTH injections for 5 days, both brain $\mathrm{Ca}^{++}$and the EEG have returned to normal (21). This situation may be analogous to normalization of the EEG with recovery of renal function in patients with acute renal failure (Figs. 1 and 2). In chronic states of PTH excess, the situation is different. In patients with hyperparathyroidism, brain $\mathrm{Ca}^{++}$is elevated $(22)$; the EEG is abnormal $(22,23)$ and improves toward normal after parathyroidectomy, but not for several months (22). In these patients, then, the EEG is abnormal although PTH levels are in the normal range (22). It is a reasonable assumption that brain $\mathrm{Ca}^{++}$might return toward normal more rapidly in patients whose acute renal failure (and acute hyperparathyroidism) is relieved than in patients with long standing hyperparathyroidism. Thus, the EEG changes may actually correlate best with changes in brain $\mathrm{Ca}^{++}$ content.

Our patients (Figs. 1 and 2) had normal EEGs during the diuretic phase of acute renal failure. The most likely explanation is that with amelioration of the uremia, brain $\mathrm{Ca}^{++}$rapidly returned toward normal. Parathyroid hormone levels were not evaluated during the diuretic phase of the acute renal failure in the present study. However, both renal excretion and renal metabolism are major routes for disposal of PTH (24, $25)$. It is possible that with the onset of the diuretic 
phase of acute renal failure, plasma PTH levels might rapidly return toward normal.

There are very few measurements of brain electrolytes in man, which is due in part to the difficulties in obtaining suitable tissue samples. Also, human brain samples will usually be obtained at least $24 \mathrm{~h}$ post mortem. Our values for normal human brain are very similar to those reported by other investigators for $\mathrm{H}_{2} \mathrm{O}, \mathrm{Na}^{+}, \mathrm{K}^{+}$, and $\mathrm{Cl}^{-}(26)$, and $\mathrm{Ca}^{++}$and $\mathrm{Mg}^{++}$ (26-28).

Several additional lines of evidence suggest that the EEG abnormalities in patients with acute renal failure may be related to elevations of brain $\mathrm{Ca}^{++}$content. (a) Studies in animals have shown that hemodialysis results in a fall of brain $\mathrm{Ca}^{++}$content (11). (b) In the present study, brain $\mathrm{Ca}^{++}$content in patients treated for at least $6 \mathrm{mo}$ with hemodialysis $(32.2 \pm 1.6 \mathrm{meq} / \mathrm{kg}$ dry wt) was significantly less $(P<0.025)$ than that in patients with acute renal failure $46.5 \pm 3.2 \mathrm{meq} / \mathrm{kg}$ dry wt). (c) The EEGs in patients with chronic renal failure treated with dialysis tend to approach a normal pattern (6-9), whereas those in patients with acute renal failure are grossly abnormal (8) (Figs. 1 and 2).

Factors other than hyperparathyroidism and acute renal failure which might contribute to the observed EEG abnormalities include coexisting hypoxia, hyponatremia, hypoglycemia, and advanced liver disease (29). However, EEGs on patients who had such contributing factors were not included in this study. Furthermore, previous studies in animals (10) have shown that neither changes in systemic acid base balance nor plasma electrolytes could account for the EEG changes observed in acute renal failure. Cerebral edema may also produce EEG abnormalities. However, brain water was normal both in our patients (Table I) as well as in others with acute renal failure (30).

Changes in brain electrolytes other than $\mathrm{Ca}^{++}$might also affect the EEG. In the patients with acute renal failure, brain content of $\mathrm{K}^{+}, \mathrm{Mg}^{++}$, and water were similar to normal values (Table $\mathrm{I}$ ). Brain content of $\mathrm{Na}^{+}$was significantly less than normal (Table I). This also has been observed in dogs with acute renal failure (17). However, similar EEG changes are observed in hyperparathyroid but nonazotemic dogs, in whom brain $\mathrm{Na}^{+}$is normal (10). The significance of the depressed brain $\mathrm{Na}^{+}$in uremic subjects is not known at this time.

A normal EEG depends on the integrity of both cerebral cortex and deeper brain structures, and most metabolic abnormalities which depress sensorium will also affect the EEG in a parallel manner $(29,31)$. Other causes of coma do not generally produce diffuse slowing of the EEG, so that such findings usually indicate a severe cerebral metabolic disturbance.

The exact cause of the elevated levels of PTH in our patients with acute renal failure is not fully eluci- dated. It has previously been suggested that either phosphate retention (32), a primary resistance to the skeletal action of PTH (18), or a deficiency of one of the active metabolites of vitamin D (33) might be contributing factors. Any of these conditions could lead to a fall in plasma $\mathrm{Ca}^{++}$concentration, resulting in an increase in plasma PTH levels. There is also some recent data which suggests that impaired renal degradation of PTH plays a role in the elevated plasma PTH levels seen in patients with renal failure (24). All of the aforementioned conditions were probably present in our patients, and the experimental design does not permit further elucidation of the cause of the elevated PTH levels.

The exact mode of action of PTH on brain tissue is not known. Other studies suggest that an elevation in the plasma $\left(\mathrm{Ca}^{++}\right)\left(\mathrm{PO}_{4}^{---}\right)$product can lead to soft tissue calcification (34). Such a sequence is highly unlikely in the present study for several reasons: $(a)$ There was no correlation $\left(r^{2}=0.14, P>0.05\right)$ between the brain $\mathrm{Ca}^{++}$content vs. the plasma $\left(\mathrm{Ca}^{++}\right)\left(\mathrm{PO}_{4}^{---}\right)$ product in nine normal subjects and 15 patients with renal failure (Fig. 5); (b) Most of our patients were hypocalcemic (Fig. 4); (c) The mean $\left(\mathrm{Ca}^{++}\right)\left(\mathrm{PO}_{4}^{---}\right)$ product in our patients with renal failure $\left(\mathrm{Ca}^{++}=7.6\right.$ $\mathrm{mg} / \mathrm{dl} ; \mathrm{PO}_{4}^{---}=5.6 \mathrm{mg} / \mathrm{dl}$ ) did not exceed normal values. In addition to the brain, PTH has been shown to enhance entry of $\mathrm{Ca}^{++}$into several tissues, including myocardium (35), aorta (36), cornea (37), lung (11, 38), and renal cortex $(11,39)$.

PTH appears to have an effect on the permeability of several cell membranes to $\mathrm{Ca}^{++}(40)$, and this action may play a role in the increased tissue $\mathrm{Ca}^{++}$content observed in hyperparathyroid states. There are at least two channels whereby $\mathrm{Ca}^{++}$can enter cells (41). In one of these, depolarization of the cell membrane can occur as a consequence of interaction of PTH with a receptor site, leading to activation of membranebound adenyl cyclase. This would lead to a resultant increase of intracellular cyclic AMP with possible inhibition of phosphodiesterase (41). There are in brain several $\mathrm{Ca}^{++}$binding phosphoproteins, adenyl cyclose, and a phosphodiesterase (42). The resultant membrane depolarization will lead to an increase in permeability of the potential-dependent $\mathrm{Ca}^{++}$channel, with a subsequent rise in intracellular $\mathrm{Ca}^{++}$content (41).

The normal intracellular free $\mathrm{Ca}^{++}$concentration in brain as well as other neural tissues is probably less than $10 \mu \mathrm{mol} /$ liter $(41,43)$. There are a large number of $\mathrm{Ca}^{++}$mediated processes in neural cells (neurotransmitter activity, substrate transport, protein synthesis) (41) and alterations of intracellular $\mathrm{Ca}^{++}$content could interfere with any of these processes, which might in part account for the observed EEG changes.

The MNCV in our patients was not affected by acute renal failure (Fig. 4). In one study of motor nerve func- 
tion in a patient with acute renal failure, MNCV was normal (5) with minimal elevation in the threshold of excitability, although there was evidence of segmental damage to the Schwann cell-myelin sheath. Thus, MNCV may be too crude a functional test to evaluate minimal changes in peripheral nerve function $(1,3)$. However, our data suggests that neither a specific "uremic toxin" nor the presence of a uremic environment (44) is enough to cause acute measurable alterations in MNCV (45). It appears, rather, that progressive anatomical nerve damage (segmental demyelination, decrease in axis cylinder diameter, axonal degeneration) is largely responsible for uremic peripheral neuropathy $(4,46)$. Because such changes usually take several months to occur, it is perhaps not surprising that our acute renal failure patients had no impairment in MNCV.

In general, it appears that in patients with acute renal failure for less than $48 \mathrm{~h}$ there are elevated plasma PTH levels. Accompanying the high PTH levels are an increased brain $\mathrm{Ca}^{++}$content and an abnormal EEG. The EEG is unaffected by dialysis but returns to normal with return of renal function (Figs. 1 and 2). It is unlikely that an elevated brain $\mathrm{Ca}^{++}$is the only biochemical abnormality in the brain which contributes to an abnormal EEG in patients with renal failure. Many other neurochemical alterations have been described in the brain of animals with acute renal failure $(1,3)$. It is probable that other mechanisms also contribute to the EEG abnormalities observed in patients with acute renal failure, but demonstration of such factors is at present lacking. Thus, PTH may be a major uremic toxin, showing evidence of possible central nervous system toxicity when there are only minimal abnormalities of other biochemical markers of acute renal failure.

\section{ACKNOWLEDGMENTS}

Art work was done by Bob Surface (Medical Research Graphics, San Francisco, Calif.).

This research was supported by contract N01-AM-5-2204 from the Chronic Uremia-Artificial Kidney Program, National Institute of Arthritis, Metabolism, and Digestive Diseases, National Institutes of Health.

\section{REFERENCES}

1. Raskin, N. H., and R. A. Fishman. 1976. Neurologic disorders in renal failure. N. Engl. J. Med. 294: 143-148, 204-210.

2. Locke, S., J. P. Merrill, and H. R. Tyler. 1961. Neurologic complications of acute uremia. Arch. Intern. Med. 108: 75-86.

3. Tyler, H. R. 1968. Neurologic disorders in renal failure. Am. J. Med. 44: 734-748.

4. Thomas, P. K., K. Hollinrake, R. G. Lascelles, D. J. O'Sullivan, R. A. Baillod, J. F. Moorhead, and J. C. Mackenzie. 1971. The polyneuropathy of chronic renal failure. Brain. 94: $761-780$.
5. Dyan, A. D., C. G. Thorpe, P. F. Down, and R. I. Gleadle. 1970. Peripheral neuropathy in uremia. Neurology. 20: 649-658.

6. Jacob, J. C., P. Gloor, O. H. Elwan, J. B. Dossetor, and V. R. Pateras. 1965. Electroencephalographic changes in chronic renal failure. Neurology. 15: 419-429.

7. Hagstam, K. E. 1971. EEG frequency content related to chemical blood parameters in chronic uremia. Scand. J. Urol. Nephrol. 7(Suppl. 1): 1-56.

8. Kiley, J., and O. Hines. 1965. Electroencephalographic evalution of uremia. Arch. Intern. Med. 116: 67-73.

9. Kiley, J. E., M. W. Woodruff, and K. L. Pratt. 1976. Evaluation of encephalopathy by EEG frequency analysis in chronic dialysis patients. Clin. Neph. 5: 245-250.

10. Guisado, R., A. I. Arieff, and S. G. Massry. 1975. Changes in the electroencephalogram in acute uremia: Effects of parathyroid hormone and brain electrolytes. J. Clin. Invest. 55: 738-745.

11. Arieff, A. I., and S. G. Massry. 1974. Calcium metabolism of brain in acute renal failure: Effects of uremia, hemodialysis, and parathyroid hormone. J. Clin. Invest. 53: 387-392.

12. Engel, G. L., J. Romano, E. B. Ferris, J. P. Webb, and C. D. Stevens. 1944. A simple method of determining frequency spectra in the electroencephalogram: observations on physiological variations in glucose, oxygen, protein, and acid-base balance on the normal electroencephalogram. Arch. Neurol. Psychiatry. 51: 124-146.

13. Laidlaw, J. 1959. The application in general medical conditions of a visual method of assessing and representing generalized electroencephalographic abnormalities. J. Neurol. Neurosurg. Psychiatry. 22: 69-76.

14. Smorto, M. P., and J. V. Basmajian. 1972. Clinical Electroneurography. The Williams \& Wilkins Co., Baltimore, Md. 167-169.

15. Lindall, A. W., and E. T. Wong. 1975. Column chromatography of human serum parathyroid immunoreactive peptides. Proc. Soc. Exp. Biol. Med. 148: 799-804.

16. Bradbury, M. B., C. R. Kleeman, H. Bagdoyan, and A. Berberian. 1968. The calcium and magnesium content of skeletal muscle, brain, and cerebrospinal fluid as determined by atomic absorption flame photometry. J. Lab. Clin. Med. 71: 884-892.

17. Arieff, A. I., S. G. Massry, A. Barrientos and C. Kleeman. 1973. Brain water and electrolyte metabolism in uremia: Effects of slow and rapid hemodialysis. Kidney Int. 4: $177-187$.

18. Massry, S. G., A. I. Arieff, J. W. Coburn, G. Palmieri, and C. R. Kleeman. 1974. Devalent ion metabolism in patients with acute renal failure. Studies on the mechanism of hypocalcemia. Kidney Int. 5: 437-445.

19. Kovithavongs, T., F. O. Becker, and T. S. Ing. 1972. Parathyroid hyperplasia in acute renal failure. Nephron. 3: $349-355$.

20. Jastak, J. T., A. B. Morrison, and G. L. Raisz. 1968. Effect of renal insufficiency on parathyroid gland and calcium homeostasis. Am. J. Physiol. 215: 84-89.

21. Goldstein, D. A., and S. G. Massry. 1978. Effect of parathyroid hormone administration and its withdrawal on brain calcium and electroencephalogram. Mineral \& Elect Metabol. In press.

22. Cogan, M., C. Covey, A. I. Arieff, V. Lazarowitz, A. Wisniewski, and O. Clark. 1977. Effects of hyperparathyroidism on the central nervous system. Kidney Int. 12: 455. (Abstr.)

23. Allen, E. M., D. Malamed, and F. R. Singer. 1970. Electroencephalographic abnormalities in hypercalcemia. Neurology. 20: 15-22. 
24. Martin, K. J., K. A. Hruska, J. Lewis, C. Anderson and E. Slatopolsky. 1977. The renal handling of parathyroid hormone: role of peritubular uptake and glomerular filtration. J. Clin. Invest. 60: 808814.

25. Hruska, K. A., K. Martin, P. Mennes, A. Greenwalt, C. Anderson, S. Klahr, and E. Slatopolsky. 1977. Degradation of parathyroid hormone and fragment production by the isolated perfused dog kidney. J. Clin. Invest. 60: 501-510.

26. Dickerson, J. T. 1968. The composition of nervous tissues. In Applied neurochemistry. A. N. Davison and J. Dobbing, editors. F. A. Davis Co., Philadelphia. 48-115.

27. Widdowson, E. M. and J. T. Dickerson. 1960. The effect of growth and function on the chemical composition of soft tissues. Biochem. J. 77: 30-43.

28. Alfrey, A. C., J. M. Mishell, J. Burks, S. R. Contiguglia, H. Rudolph, E. Lewin, and J. H. Holmes. 1972. Syndrome of dyspraxia and multifocal seizures associated with chronic hemodialysis. Trans. Am. Soc. Artif. Intern. Organs. 18: 257-261.

29. Plum, F., and J. B. Posner. 1966. Metabolic brain diseases causing coma. In Diagnosis of stupor and coma. F. A. Davis Co., Philadelphia. 132-136.

30. Olsen, S. 1961. The brain in uremia. Acta. Psychiatr. Scand. 36 (Suppl. 156): 1-128.

31. Romano, J., and G. L. Engel. 1944. Delirium. I. Electroencephalographic data. Arch. Neurol. Psychiatr. 51: 356-377.

32. Slatopolsky, E., S. Caglar, J. P. Pennell, D. G. Taggart, J. M. Canterbury, E. Reiss, and N. S. Bricker. 1971. On the pathogenesis of hyperparathyroidism in chronic experimental renal insufficiency in the dog. J. Clin. Invest. 50: 492-499.

33. Massry, S. G., R. Stein, J. Garty, A. I. Arieff, J. W. Coburn, A. W. Norman, and R. M. Friedler. 1976. Skeletal resistance to the calcemic action of parathyroid hormone in uremia: Role of $1,25(\mathrm{OH})_{2} \mathrm{D}_{3}$. Kidney Int 9: 467-474.

34. Mallick, N. P., and G. M. Berlyne. 1968. Arterial calcification after vitamin-D therapy in hyperphosphatemic renal failure. Lancet. II: $1316-1320$.

35. Terman, D. S., A. C. Alfrey, W. S. Hammond, T. Donndelinger, D. A. Ogden, and Holmes. 1971. Cardiac calcification in uremia: A clinical, biochemical, and pathologic study. Am. J. Med. 50: 744-755.

36. Bernstein, D. S., P. Pletka, R. S. Hattner, C. L. Hampers, and J. P. Merrill. 1971. Effect of total parathyroidectomy and uremia on the chemical composition of bone, skin, and aorta in the rat. Isr. J. Med. Sci. 7: 513-514.

37. Berkow, J. W., B. S. Fine, and L. E. Zimmerman. 1968. Unusual ocular calcification in hyperparathyroidism. Am. J. Opthalmol. 66: 812-824.

38. Conger, J. D., W. S. Hammond, A. C. Alfrey, S. R. Contiguglia, R. E. Stanford, and W. E. Huffer. 1975. Pulmonary calcification in chronic dialysis patients: Clinical and pathological studies. Ann. Intern. Med. 83: 330-336.

39. Borle, A. B. 1970. Kinetic analysis of calcium movements in cell cultures. IV. Effects of phosphate and parathyroid hormone in kidney cells. Endocrinology. 86: 1389-1393.

40. Rasmussen, H. 1972. The cellular basis of mammalian calcium homeostasis. In Clinics in Endocrinology and Metabolism. I. Macintyre, editor. W. B. Saunders Company, Ltd., Philadelphia. 1: 3-20.

41. Rasmussen, H., and D. B. P. Goodman. 1977. Relationships between calcium and cyclic nucleotides in cell activation: Cellular calcium metabolism and calciummediated cellular processes. Physiol. Rev. 57: 428-441.

42. Wolff, D. J., and C. O. Brostrom. 1974. Calcium-binding phosphoprotein from pig brain: Identification as a calcium-dependent regulator of brain cyclic nucleotide phosphodiesterase. Arch. Biochem. Biophys. 163: 349358.

43. Baker, P. F., A. L. Hodgkin, and E. B. Ridgway. 1971. Depolarization and calcium entry in squid giant axons. J. Physiol. (Lond.). 218: 709-75.5.

44. Liveson, J. A., J. Gardner, and M. B. Bornstein. 1977. Tissue culture studies of possible uremic neurotoxins: Myoinositol. Kidney Int. 12: 131-136.

45. Nielsen, V. K. 1973. The peripheral nerve function in chronic renal failure, VI: The relationship between sensory and motor nerve conduction and kidney function, azotemia, age. Acta. Med. Scand. 194: 455-462.

46. Dyck, P. J., W. J. Johnson, E. H. Lambert, and P. C. O'Brien. 1971. Segmental demyelination secondary to axonal degeneration in uremic neuropathy. Mayo Clin. Proc. 46: 40()-431. 